\title{
Popularity Dynamics of Social and Affordable Housing: Ethics vs Business
}

\author{
http://doi.org/10.21272/bel.5(1).109-117.2021
}

Svitlana Ianchuk, ORCID: https://orcid.org/0000-0002-0657-3040

Post-Graduate student, Sumy State University; Financial Director, "Global-Trade-S” LLC, Sumy, Ukraine

\begin{abstract}
This paper summarizes the arguments and counterarguments within the scientific discussion on the issue of social housing, existing ethical dilemmas, and business development. The main purpose of the research is to investigate the interest level and popularity dynamics of social and affordable housing in the world in general and in OECD countries. The systematization of literary sources and approaches for solving the problem of ethical and economical aspects of social and affordable housing indicates that there is no single point of view on this issue among scientists. That is why the essence of the concepts of social, affordable, and public housing needs to be clarified considering existing differences. Besides it, comparative analysis of the results of analytical analysis of the interest level and popularity dynamics of social and affordable housing based on Google Trends tools and the results of statistical analysis in this context has not been conducted yet. Investigation of the topic about popularity dynamics of social and affordable housing emphasizing ethical needs and expected business benefits in the paper is carried out in the following logical sequence: systematization and clarification theoretical approaches to determine the essence and the difference between social, public and affordable housing; description of dominant types of funding social and affordable housing; analytical analysis of popularity dynamics of social and affordable housing with the determination of key value picks; statistical analysis of certain social housing indicators; comparing the results and making conclusions. Methodological tools of the research methods were logical generalization and scientific abstraction, statistical and structural analysis, comparative, and graphical analysis using the Excel software. Analytical analysis was realized based on Google Trends tools. The objects of research were the search requests about social, public, and affordable housing in the world in 2004-2021, and the indicators of social housing from the sample of OECD countries and other EU countries (limit in 2018 due to the availability of information on open information portals of The Organization for Economic Co-operation and Development). The paper presents the results of analytical, statistical, and comparative analysis of the level of interest (popularity) and development of social and affordable housing. The recommendations according to the coexistence of ethical and entrepreneurial principles can be useful for public and private investors in social and affordable housing.
\end{abstract}

Keywords: Affordable Housing, Ethical Dilemma, Housing Allowances, Inclusive Economy, Public and Private Investment, Public Housing, Social Housing, Social Rental Dwellings, Subsidies, Tenant.

JEL Classification: A13, O18, R21, R31.

Cite as: Ianchuk, S. (2021). Popularity Dynamics of Social and Affordable Housing: Ethics vs Business. Business Ethics and Leadership, 5(1), 109-117. http://doi.org/10.21272/bel.5(1).109-117.2021.

Received: 15 January 2021

Accepted: 10 March 2021

Published: 30 March 2021

Copyright: (C) 2021 by the author. Licensee Sumy State University, Ukraine. This article is an open access article distributed under the terms and conditions of the Creative Commons Attribution (CC BY) license (https://creativecommons.org/licenses/by/ 4.0/).

\section{Introduction}

On the one hand, rising housing prices, inflation, wage stagnation, demographic situation are only a few reasons for the negative impact on housing affordability in many European countries and generally in the world. On the other hand, declining public investment in affordable housing influences the level of housing affordability negatively too. Especially, since the global financial crisis of 2008, increasing numbers of lowand middle-income households have been struggling to afford housing (The OECD Housing Project). Of course, social, and affordable housing looks and functions very differently across countries. Key differences are related to the target population, social housing subjects, social housing providers, and funding social and affordable housing. Before the COVID-19 crisis, house prices had been increasing dramatically in many countries, mostly for renters, and the supply of affordable housing has failed to meet demand. The COVID-19 pandemic exposed longstanding housing affordability and quality gaps, prompting a range of temporary support measures (OECD, Social housing, 2020). Thus, finding affordable housing is difficult, especially for families with children and seniors, young people, students, and visiting workers, for those with unstable or low incomes. 
Social and affordable housing is essential for many people's well-being and a sustainable and inclusive economy in general (OECD, Housing, and Inclusive Growth, 2020). Investment in social housing can help address enduring affordability gaps and help build an inclusive economic recovery (OECD, 2021). What is more important, housing covers most areas of public, economic, financial, and social policy, from humanistic and ethical points to economic growth and labor mobility on different levels - local, national, and international. Besides, modern housing policies and strategies are characterized by low efficiency. Renewed public and private investment in the affordable and social housing stock is needed. Governments need to invest more in affordable and social housing. Policy measures to make the private rental market more affordable should also be a priority. That is why the issue of social housing, existing ethical dilemma, and business development, and the investigation of popularity dynamics of social and affordable housing arouse considerable interest. The main purpose of the research is to investigate the interest level and popularity dynamics of social and affordable housing in the world in general and in OECD countries in particular.

\section{Literature Review}

The problem of social and affordable housing is not new in contemporary science. The first and foremost ethical and business aspects were the subject of many scholars' attention. The relationship between ethics and economics is often debated (Hausman, et al., 2016). The main preconditions for the emergence of poverty and inequality in the distribution of housing among the population, the problem of increasing speculation in the real estate market, and the lack of an effective state housing policy were discussed too (Sanchez, 2020). In particular, Iglesias (2007) explored housing ethics that have historically shaped USA housing law and policy (housing as an economic good, housing as providing social order, etc.). The author argued that coexistence and pluralism among housing ethics were the norms. He examined the challenges and opportunities that housing ethic pluralism presented to the affordable housing movement.

Elsinga et al. (2020) proved the role of values in housing policy and design based on the Design for Values approach considering such moral values as inclusiveness, sustainability, autonomy, and security. In contrast, Blower (2017) investigated 'ethical dilemma and argued that commercialism could generate greater profits for social purpose. Furthermore, Finney (2020) grounded that an investment in affordable housing can be both a business and an investment strategy. Besides it, there is a strong necessity for housing that is affordable for people further up the income scale. Without it, there are serious consequences for attracting the entrepreneurs and young professionals who have traditionally fueled the city's growth, creativity, and innovation (Kerslake et al., 2016). The issues of energy efficiency and technical conditions of the housing stock, existing reserves for optimization of energy consumption, household income levels and their real capacity to participate in state and regional energy efficiency programs, the introduction of the policies of social protection and welfare benefits (subsidies) are common too (Komelina \& Shcherbinina, 2018).

Systematization of these and other literary sources and approaches to solve the problem of ethical and economical aspects of social and affordable housing indicates that there is no single point of view on this issue among scientists. That is why the concepts of social, affordable, and public housing need to be clarified considering existing differences. The comparative analysis of the results of analytical analysis of the interest level and social and affordable housing popularity dynamics based on Google Trends tools and the statistical analysis results in this context has not been conducted yet.

\section{Methodology and Research Methods}

Methodological tools of the research methods include logical generalization and scientific abstraction, statistical and structural analysis, comparative, and graphical analysis using the Excel software. The analytical analysis is realized based on Google Trends tools. The objects of research are the search requests about social, public, and affordable housing in the world in 2004-2021, and the certain indicators of social housing from the sample of OECD countries and other EU countries (limit in 2018 due to the availability of information on open information portals of The Organization for Economic Co-operation and Development). There was also a comparative analysis of the results of analytical analysis of the interest level and popularity dynamics of social and affordable housing based on Google Trends tools, and the results of statistical analysis in this context. We proved the hypothesis about the interconnection between investigated indicators and approaches. The top countries with a high level of social and affordable housing were identified.

\section{Results}

Social housing is an important dimension of affordable housing provision and social welfare policy, representing more than 28 million dwellings and about $6 \%$ of the total housing stock, for example of OECD 
and non-OECD EU countries. However, there are significant differences from country to country in the definition, scope, size, type of provider of social housing, target population etc. For instance, social rental housing makes up less than 10\% of the total dwelling stock in most OECD and EU countries, but more than $20 \%$ of the total stock in Denmark, Austria, and the Netherlands, where it represents the "third sector" in the housing market (OECD, Social housing, 2020). Let us analyze the essence of social housing. According to Cambridge Advanced Learner's Dictionary social housing means houses and flats that are owned by local government or by other organizations that do not make a profit, and that are rented to people who have low incomes (Social housing, Cambridge Advanced Learner's Dictionary \& Thesaurus). It is a home provided by the government for people with low incomes to rent cheaply (Social housing, Cambridge Business English Dictionary).

Also, social housing is a residential rental accommodation provided at sub-market prices, targeted, and allocated according to specific rules, such as identified needs or waiting lists (Salvi del Pero et al., 2016). Social housing properties are usually owned by the state, in the form of councils, or by non-profit organizations, particularly, housing associations. Besides, social housing is associated with subsidized housing in Germany, Canada, Australia, and other countries. In the United Kingdom, social housing is a council one. In Denmark, it is general housing. In Austria, Latvia, and Lithuania social housing is municipal housing, etc. Thus, it is necessary to differ social housing from the public (governmental) one. Firstly, social housing is public housing, but only financed by government. European social housing is subsidized yet serves middleclass as well as low-income households, thereby avoiding many of the socio-economic issues associated with America's public housing. The author emphasizes that we should take a cue from Europe, where such countries as Denmark and Austria build social housing and consider building workforce housing sponsored and funded directly by the public sector (Lewis, 2013). We agree that it is important to create new affordable housing, for which demand is growing while supply is shrinking nowadays.

Secondly, the concept of social housing should be distinguished from the concept of affordable housing, which refers to rental and owner-occupied dwellings that are made more affordable to households through a broad range of supply- and demand-side supports (for example, housing allowances, subsidies, tax relief to first-time homeowners, etc.) (OECD, Social housing, 2020). Besides, housing affordability can be broadly defined as the ability of households to buy or rent adequate housing, without impairing their ability to meet basic living costs (OECD, 2021). Thus, affordable housing is not the same as social housing. Affordable housing is open to a broader range of household incomes than social housing. Households do not have to be eligible for social housing to apply for affordable housing, though people who are eligible for social housing may also be eligible for affordable housing properties. Also, affordable housing is managed more like private rental property, but there are eligibility criteria, and the managers are mostly not-for-profit community housing providers. Moreover, rents for affordable housing are usually calculated differently from social housing and there are different tenancy arrangements (NSW Government). In the context of this research, we analyze the level of interest and popularity dynamics of the search requests about social, affordable, and public housing in 2004-2021 based on the Google Trends tool (Figure 1).

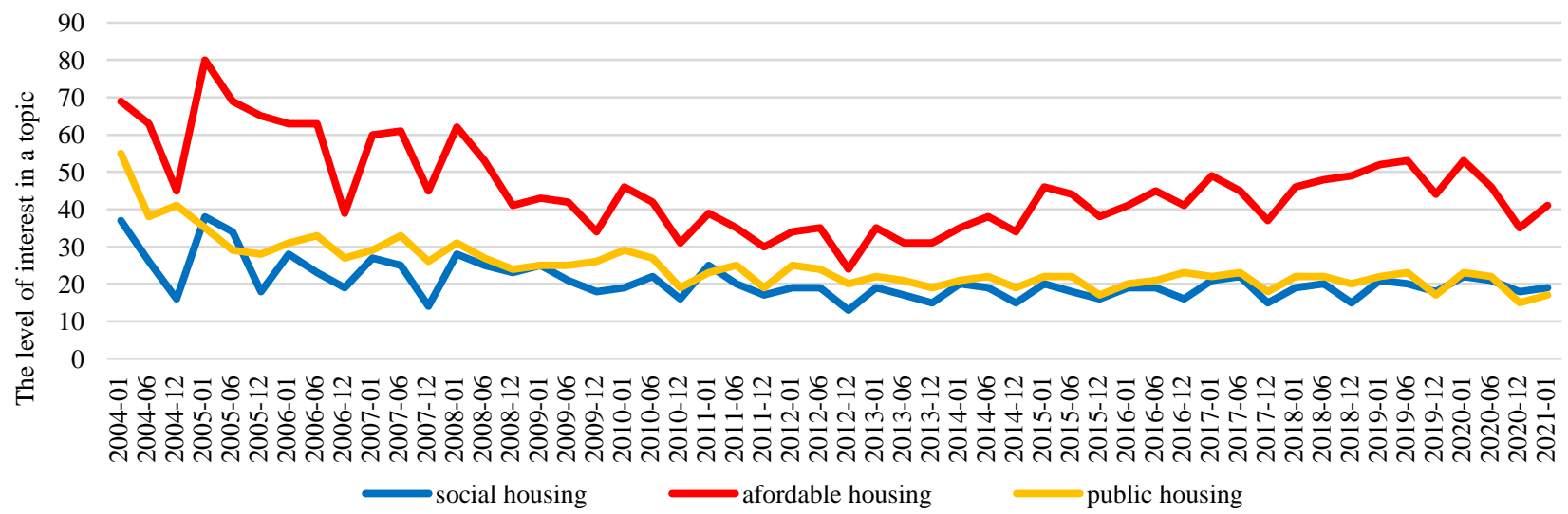

Figure 1. Analytical Analysis of Popularity Dynamics of the Search Requests about Social, Affordable, and Public Housing over the World in 2004-2021

Source: Developed by the author based on Google Trends tools

The popularity value indicates the level of interest (by search request) in a certain topic (social housing, affordable housing, and public housing) about the highest score for a particular region (all over the world) and period (from January 2004 to January 2021). 100 points mean the highest level of popularity of the request, 50 - 
the level of popularity of the request, half as compared to the first case. 0 points mean a location for which there is not enough data on the request in question. Thus, we concluded the lowest level of popularity of the search request about social housing was at the end of 2007. In our opinion, the reason was related to the global financial crisis. Other picks related to the decrease of the popularity of the search requests about all investigated housing types are in 2012 and 2020. The last one relates to the COVID-19 crisis. Besides, this investigation shows that popularity dynamics of the search requests about social housing and public housing are interconnected compared with the popularity dynamics of the search request about affordable housing. It means that people often match social and public housing as the same concepts. However, the popularity dynamics of the search request about affordable housing has a similar trend but with a higher interest due to the wider and more common context of this concept. Also, we made special maps to visualize the popularity level of search requests in different regions by specifying a search in Google Trends (Figure 2).

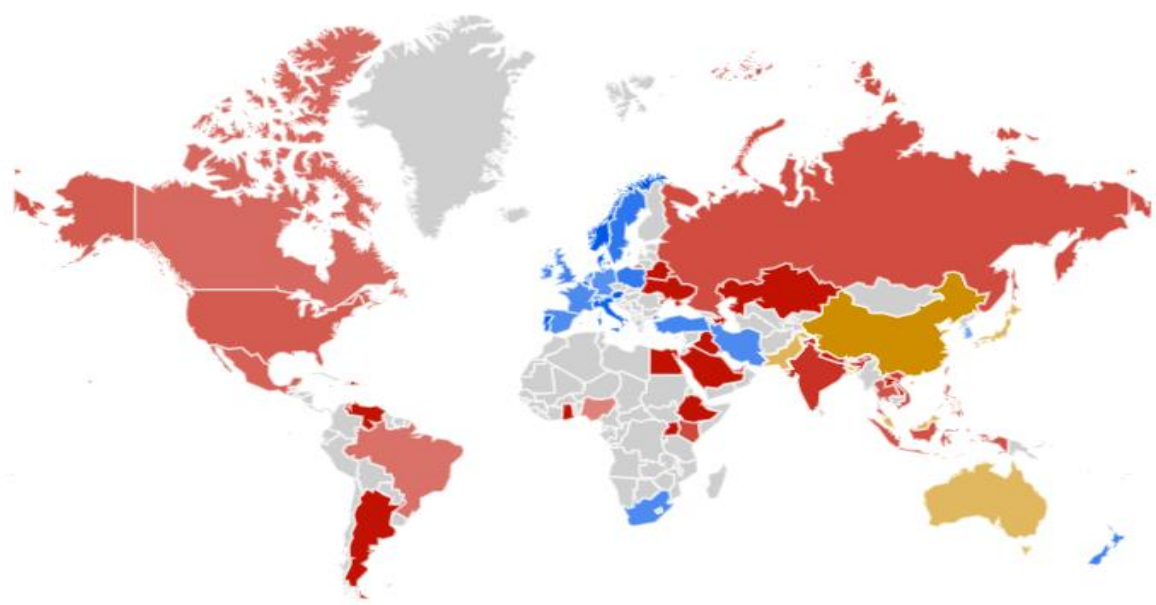

Figure 2. The World Visualization Map of Popularity Level of the Search Requests about Social, Affordable, and Public Housing in 2004-2021

* Blue - social housing; red-affordable housing; orange - public housing

** The darker the selected area, the more often searches for the phrase users entered

*** For comparing multiple searches, the color intensity for each region reflected the percentage of searches for the top search term in that region. The popularity of a request was measured relative to the total number of requests in Google Search in each region over an investigated time

Source: Developed by the author based on Google Trends tools

The separate map to compare breakdown by region for the search request about social housing is presented on Figure 3.

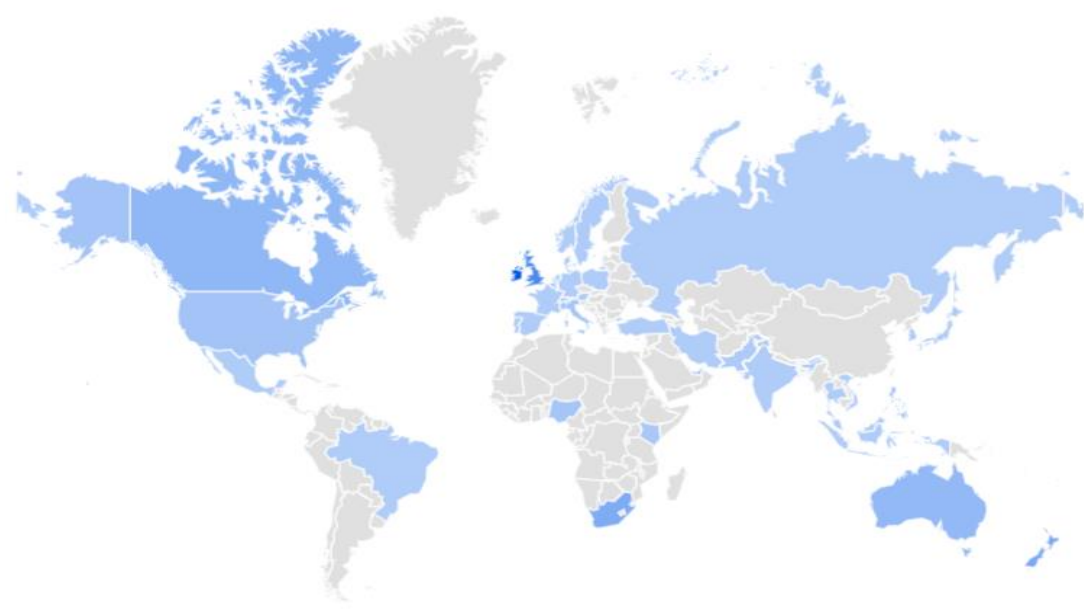

Figure 3. The Visualization Map of Popularity Level of the Search Request about Social Housing in 2004-2021

* The darker the selected area, the more often searches for the phrase users entered

Source: Developed by the author based on Google Trends tools

So, leading countries in terms of popularity of search requests about social housing are Portugal, Denmark, Austria, New Zealand, United Kingdom, Ireland, South Africa, Germany, Philippines, and Canada. Besides, 
dominant search requests about social housing include "social housing rent", "what is social housing", "social house", "social security office", "social housing list", etc. We show the world visualization map to compare breakdown by region for the search request about affordable housing in Figure 4.

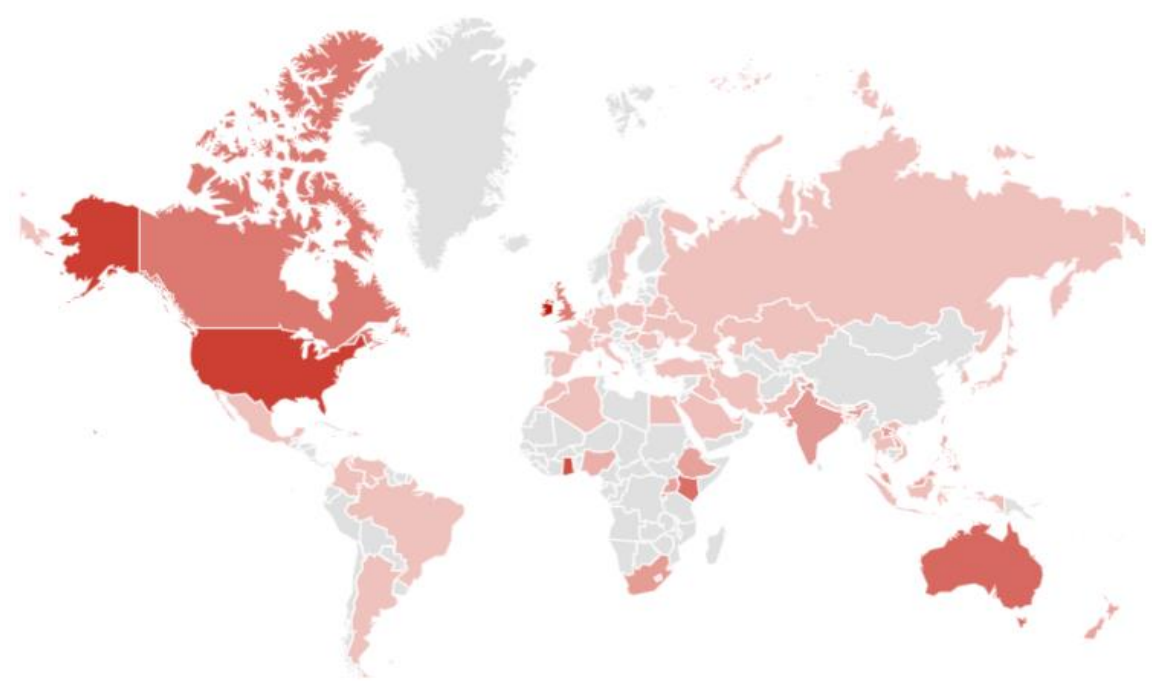

Figure 4. The Visualization Map of Popularity Level of the Search Request about Affordable Housing in 2004-2021

* The darker the selected area, the more often searches for the phrase users entered

Source: Developed by the author based on Google Trends tools

We conclude that the highest level of interest in affordable housing is in Ghana, India, Indonesia, United States, Vietnam, Canada, the Philippines, Malaysia, and Australia. One should note that top search requests about affordable housing include such ones as "affordable housing NYC", "NJ affordable housing", "apartments for rent", "Gurgaon affordable housing", "affordable housing near me" etc. The visualization map to compare breakdown by region for the search request about public housing is presented in Figure 5.

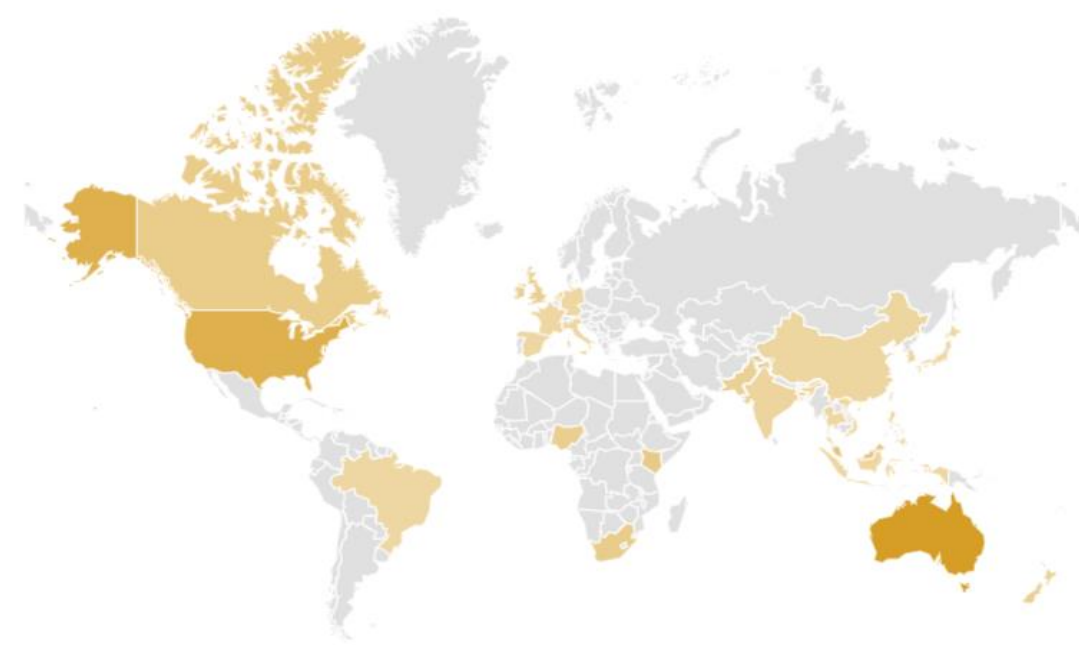

Figure 5. The Visualization Map of Popularity Level of the Search Request about Public Housing in 2004-2021

* The darker the selected area, the more often searches for the phrase users entered

Source: Developed by the author based on Google Trends tools

Thus, the highest level of interest in public housing is in Singapore, Malaysia, Australia, Nigeria, United States, Germany, Indonesia, South Africa, Canada, and New Zealand. Besides, dominant search requests about public housing include "housing application", "public house", "public housing application", "NYC public housing", "NYC housing" etc. We define top-20 European countries in social housing based on the number of social rental dwellings as a share of the total number of dwellings retrieved from the OECD Affordable Housing Database (Figure 6) to compare received conclusions from the analytic analysis. 


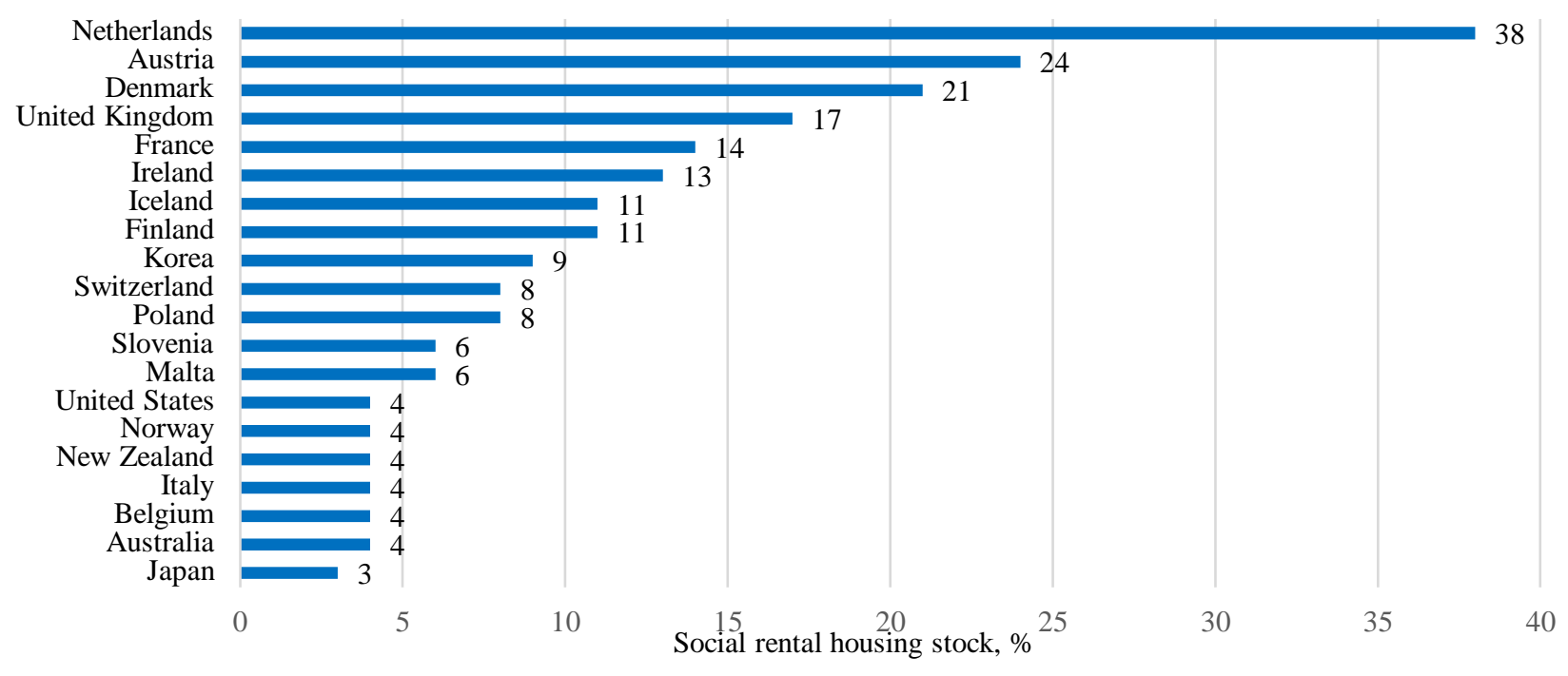

Figure 6. Top-20 European Countries in Social Housing in 2018

Source: Developed by the author based on OECD Affordable Housing Database (Social Housing), 2018

We determine that the biggest share of social rental dwellings is in the Netherlands, Austria, Denmark, United Kingdom, and Ireland. That is why we grounded that the results of the statistical and graphical analysis correspond to the results based on analytical analysis too. What is more important, in most OECD countries, social housing typically makes up less than $10 \%$ of the total dwelling stock. However, in Austria, Denmark, and the Netherlands, it represents a key "third sector" in the housing market, with over $20 \%$ of all housing (OECD, 2021). Government spending on housing allowances as a percent of GDP is shown in Figure 7.

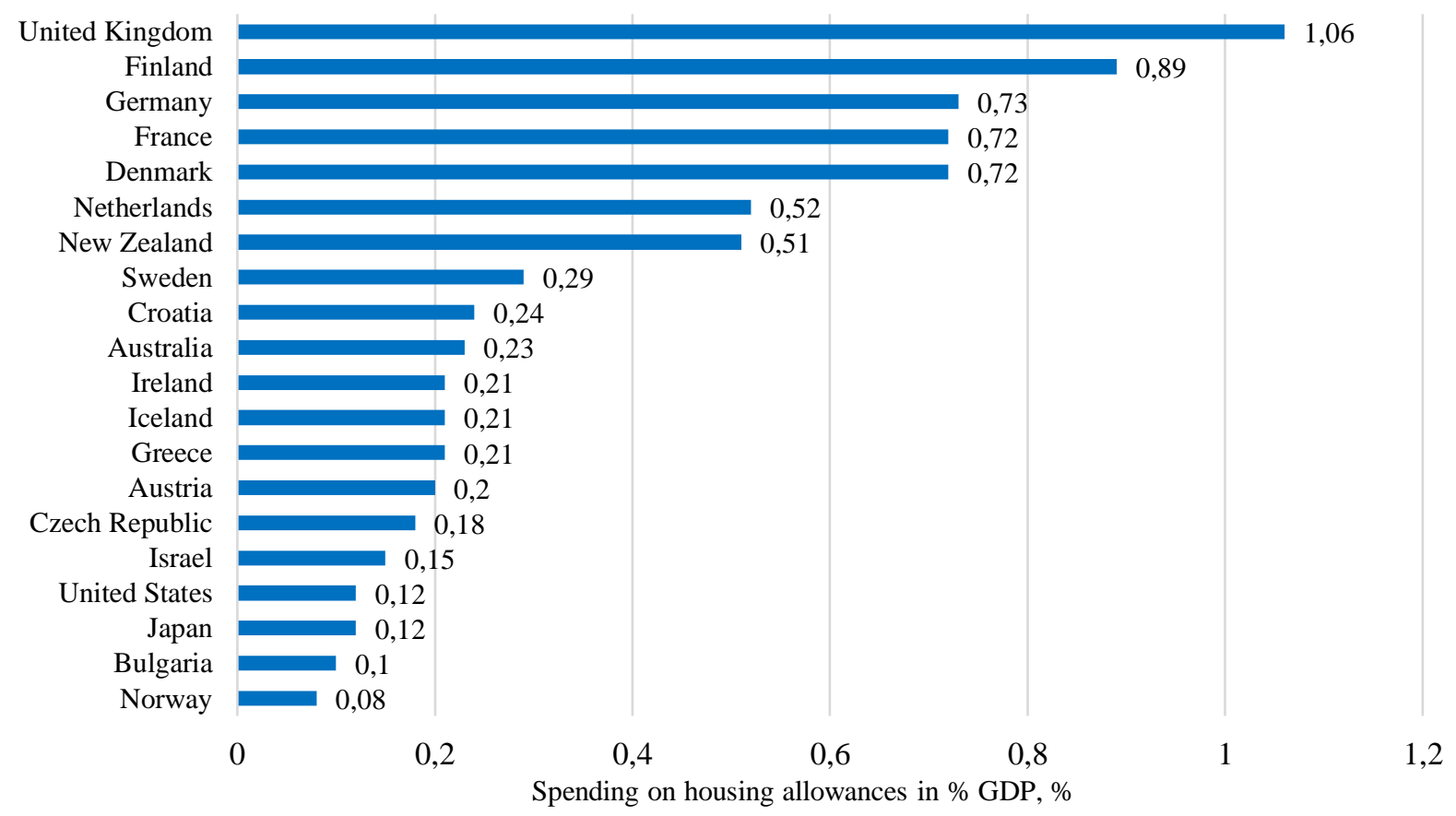

Figure 7. Top-20 European Countries in Housing Allowances by Government in 2018

Source: Developed by the author based on OECD Affordable Housing Database (Housing Allowances), 2018

So, United Kingdom, Germany, Denmark, Austria, New Zealand, Ireland, Australia, United States are among the top countries based both on statistical, graphical, and analytical analysis. To sum up it should be said that social housing target low-income and some vulnerable households. In turn, social housing providers are public, private, or non- or limited-profit entities, co-operatives, or a mix of providers (depending on the country) (OECD, Social housing, 2020). In OECD countries regional and municipal authorities account for around half of social housing provision, and the remainder is divided among non-profit, limited profit or co-operative housing associations (15\%), national governments (14\%), for-profit providers (11\%), and others (OECD, 2021). However, sub-national governments dominate social housing delivery in general. Only in the countries with large social housing stock, nonprofit developers tend to play a key role. 
We characterize the types of social and affordable housing funding to investigate the ethical and business issues of popularity dynamics of social and affordable housing. The key ones include rental income from tenants, borrowing by the social housing provider, and payments and subsidies from others, including governments. Especially governments may support the social housing supply through the direct provision of social housing, by providing grants, tax credits, loans, and loan guarantees to social housing providers, by supply land for social housing development at discounted prices (Scanlon et al., 2015). There are many modern approaches to finance innovation policies and projects including public and social ones through tax incentives, investments, or direct support, etc. (Rzayev \& Samoilikova, 2020; Samoilikova, 2020).

The prioritization of social and affordable housing is a key counter-cyclical investment opportunity that can help support jobs and SMEs in the building sector and deliver more affordable housing. Also, investments in affordable and social housing underpin mobility (Causa and Pichelmann, 2020). We strongly agree that governments need to invest more in affordable and social housing as a part of the solution as countries chart a path towards economic recovery. Reducing administrative barriers to affordable housing construction can also help expand supply. In turn, policymakers and social housing providers face several challenges and trade-offs to develop an environmentally and fiscally sustainable sector that provides quality, affordable housing to those who struggle to afford housing on the private market (OECD, 2021).

We agree that affordability is paramount to maintaining the city's status as a hub for technology, finance, and the arts and sciences. Thus, if the government wants the future to be as prosperous as its past, both economically and culturally, it needs to commit to the role affordable housing plays (Kerslake et al., 2016). Moreover, being more business-like brings bigger benefits to customers, and keeping up with the times in terms of our organizational professionalism and application of modern technologies, housing associations can strike a new balance between social purpose and commercial need in a way that re-invigorates staff (Blower). An investment in affordable housing can be both a business and an investment strategy. Property owners receive tax credits if they use a percentage of their property as affordable housing (for example, a given number of rental units in a building). Renters also receive assistance from the government in paying their rent each month (Finney, 2020). However, we strongly agree with Steve White who said in the interview with the Guardian that his way of tackling the challenges ahead is to have "a business head and a social heart" (Murray, 2011). At the same time, in our opinion, affordable housing providers also need to be sure that their ethical motives will not be used as an excuse to avoid responsible work and so on.

\section{Conclusions}

As a result of research, we proved the importance of improving housing policies and strategies with the accent on public and private partnership considering a strong necessity of affordable housing for a lot of people. We summed up and analyzed the theoretical approaches to the determination of concepts of "social housing", "affordable housing", and "public housing", and identified key differences between these ones: 1) social and public housing mostly have similar meaning: social housing is public because it is financed or subsidized by public sector (state and local government, councils, non-profit organizations such as housing associations, etc.); 2) the concept of affordable housing is broader than the concept of social housing (the first one is open to a broader range of household incomes than the last one); 3) social housing is a residential rental accommodation while affordable housing refers to rental and owner-occupied dwellings; 4) affordable housing cover housing allowances, subsidies, tax relief to first-time homeowners etc., and it is managed more like a private rental property; 5) rents for affordable housing are usually calculated differently to social housing and there are different tenancy arrangements. Also, we grounded the necessity to solve the dilemma between ethical, and business motivation when we are investing in social and affordable housing. We are sure both ethics and business targets in this area can bring benefits in the context of a sustainable, efficient, high level and inclusive economy.

We characterized the types of funding social and affordable housing to investigate the ethical and business issues of popularity dynamics of social and affordable housing. Furthermore, we analyzed the level of interest and popularity dynamics of the search requests about social, affordable, and public housing in 2004-2021 based on the Google Trends tool. We concluded the lowest level of popularity of the search request about social housing was at the end of 2007. In our opinion, the reason was related to the global financial crisis. Other picks related to the decrease of the popularity of the search requests about all investigated types of housing are in 2012 and 2020. The last one relates to the COVID-19 crisis. Besides it, this investigation shows that popularity dynamics of the search requests about social housing and public housing are interconnected compared with the popularity dynamics of the search request about affordable housing. It means that people often match social and public housing as the same concepts. However, the popularity dynamics of the search request about 
affordable housing has a similar trend but with a higher level of interest due to the wider and more common context of this concept. Also, we made special maps to visualize the popularity level of search requests about social, affordable, and public housing in different regions by specifying a search in Google Trends. Leading countries in terms of popularity of search request about social housing are Portugal, Denmark, Austria, New Zealand, United Kingdom, Ireland, South Africa, Germany, Philippines, and Canada (dominant search requests are "social housing rent", "what is social housing", "social house", "social security office", "social housing list" etc.). The highest level of interest in affordable housing is in Ghana, India, Indonesia, United States, Vietnam, Canada, Philippines, Malaysia, and Australia (top search requests are "affordable housing NYC", "NJ affordable housing", "apartments for rent", "Gurgaon affordable housing", "affordable housing near me" etc.). The highest level of interest in public housing is in Singapore, Malaysia, Australia, Nigeria, United States, Germany, Indonesia, South Africa, Canada, and New Zealand (dominant search requests are "housing application", "public house", "public housing application", "NYC public housing", "NYC housing" etc.). We determined top-20 European countries in social housing based on several social rental dwellings as a share of the total number of dwellings retrieved from the OECD Affordable Housing Database to compare received conclusions from the analytic analysis. We identified that the biggest share of social rental dwellings is in the Netherlands, Austria, Denmark, United Kingdom, and Ireland. Also, United Kingdom, Germany, Denmark, Austria, New Zealand, Ireland, Australia, United States are among the top countries in government spending on housing allowances. That is why we grounded that the results of the statistical and graphical analysis correspond to the results based on analytical analysis too.

Funding. There is no funding for this research.

\section{References}

1. Blower D. (2017). Why housing's new commercialism is good for "ethical careers". Social Housing. Available at: https://www.socialhousing.co.uk/comment/comment/why-housings-new-commercialism-isgood-for-ethical-careers-49369.

2. Causa, O., and Pichelmann, J. (2020). Should I stay or should I go? Housing and residential mobility across OECD countries. OECD Economics Department Working papers №1626, OECD Publishing. Available at: www.oecd.org/officialdocuments/publicdisplaydocumentpdf/?cote=ECO/WKP(2020)34\&docLanguage $=E n$.

3. Elsinga, M., Hoekstra, J., Sedighi, M., \& Taebi, B. (2020). Toward Sustainable and Inclusive Housing: Underpinning Housing Policy as Design for Values. Sustainability, 12(5), 1920. https://doi.org/10.3390/su12051920.

4. Finney, D. (2020). Affordable Housing: Investing for Profit. Real Estate Investing Guide. Available at: https://www.investopedia.com/articles/mortgages-real-estate/10/affordable-housing.asp.

5. Hausman, D., McPherson, M., Satz, D. (2016). Economic Analysis, Moral Philosophy, and Public Policy. University Press: Cambridge, UK. 418 p. https://doi.org/10.1017/9781316663011.

6. Iglesias, T. (2007). Our Pluralist Housing Ethics and the Struggle for Affordability. Wake Forest Law Review, 42, 511-593. Available at: https://www.researchgate.net/publication/49250698 Our Pluralist Housing Ethics and the Struggle fo r_Affordability.

7. Kerslake, B. (2016). The Business Case for Affordable Housing. The Centre for Economics and Business Research Ltd, London. Available at: https://www.peabody.org.uk/media/10773/business-case-foraffordable-housing.pdf.

8. Komelina, O., \& Shcherbinina, S. (2018). Methodology of estimation of energy reserves and energy efficiency of the housing fund of Ukraine. Marketing and Management of Innovations, 1, 382-390. http://doi.org/10.21272/mmi.2018.1-30.

9. Lewis, R.K. (2013). Let's go from "public housing" to "social housing". The Washington Post. Available at: $\quad$ https://www.washingtonpost.com/realestate/lets-go-from-public-housing-to-socialhousing/2013/05/02/2f96427e-b1a7-11e2-baf7-5bc2a9dc6f44_story.html.

10.Murray, K. (2011). A moral maze: can housing sustain its ethical role? The Guardian. Available at: https://www.theguardian.com/housing-network/2011/nov/07/moral-maze-housing-ethical-role.

11.NSW Government (n.d.). About affordable rental housing. Available at: https://www.facs.nsw.gov.au/providers/housing/affordable/about/chapters/how-is-affordable-housingdifferent-to-social-housing.

12.OECD (2018). Affordable Housing Database. Housing Allowances. Available at: http://www.compareyourcountry.org/housing/en/2//datatable/.

13.OECD (2018). Affordable Housing Database. Public policies towards affordable housing. Available at: http://www.oecd.org/housing/data/affordable-housing-database/housing-policies.htm. 
14.OECD (2018). Affordable Housing Database. Social Housing. Available at: http://www.compareyourcountry.org/housing/en/3/all/default.

15.OECD (2020). Housing and Inclusive Growth. OECD Publishing, Paris. https://doi.org/10.1787/6ef36f4b-en.

16.OECD (2020). Social housing: A key part of past and future housing policy. Employment, Labour and Social Affairs Policy Briefs. OECD, Paris. Available at: http://oe.cd/social-housing-2020.

17.OECD (2021). Building for a better tomorrow: Policies to make housing more affordable. Employment, Labour and Social Affairs Policy Briefs. OECD, Paris. Available at: http://oe.cd/affordable-housing-2021.

18.OECD Housing Project (n.d.). Affordable housing. Available at: http://www.oecd.org/housing/topics/affordable-housing/.

19.Rzayev, A., \& Samoilikova, A. (2020). Innovation Financing Structure as a Factor of Economic Growth: Cross Country Analysis. Marketing and Management of Innovations, 3, 133-156. http://doi.org/10.21272/mmi.2020.3-10.

20.Salvi del Pero, A. (2016). Policies to promote access to good-quality affordable housing in OECD countries. OECD Social, Employment and Migration Working Papers, 176, OECD Publishing, Paris. https://dx.doi.org/10.1787/5jm3p5gl4djd-en.

21.Samoilikova, A.V. (2020). Analiz podatkovoho stymulyuvannya yak skladovoyi finansovoyi polityky zabezpechennya innovatsiynoho rozvytku [Analysis of Tax Incentives as A Component of Financial Policy of Innovative Development]. Scientific bulletin of Polissia, 1(20), 85-91 [in Ukrainian]. https://doi.org/10.25140/2410-9576-2020-2-1(20)-85-91.

22.Sanchez, C. (2020). Poverty and Inequality in Access to Housing in Mexico City During Neoliberalism. SocioEconomic Challenges, 4(2), 31-43. https://doi.org/10.21272/sec.4(2).31-43.2020.

23.Scanlon, K., Fernández Arrigoitia, M., and Whitehead, C. (2015). Social housing in Europe. European Policy Analysis, Swedish Institute for European Policy Studies. Available at: http://eprints.1se.ac.uk/62938/1/Fernandez_Social\%20housing\%20in\%20Europe_2015.pdf.

24.Social housing (n.d.). Cambridge Advanced Learner's Dictionary \& Thesaurus. Available at: https://dictionary.cambridge.org.

25.Social housing (n.d.). Cambridge Business English Dictionary. Available at: https://dictionary.cambridge.org/. 